\title{
A Tactile Display Used Phantom Sensation with Apparent Movement Together
}

\author{
Shintaro Ueda Non-member (The University of Electro-Communications, taro@zidane.ee.uec.ac.jp) \\ Masafumi Uchida Member (The University of Electro-Communications, uchi@ee.uec.ac.jp) \\ Akio Nozawa Member (Meisei University, akio@ee.meisei-u.ac.jp) \\ Hideto Ide Member (Aoyama Gakuin University, ide@ee.aoyama.ac.jp)
}

Keywords: tactile display, phantom sensation, apparent movement, information presentation

When more than one stimulus are arranged spatially, an illusion such as the phantom sensation (P.S.) and the apparent movement (A.M.) appear in the sense of touch. The former is the sense it can feel that there is just one stimulus in the gap of two stimuli. On the other hand, the latter is the sense it can feel one stimulus just to be moved between the stimulus and the stimulus and to be here. The foundation research which made the tactile display of presenting two-dimensional information by making the P.S. and the A.M. appear at the same time a goal is done by this research. When the A.M. is used, information in the direction can be expressed between 2 elements of tactile stimulus in two-dimensional vector information. In this report, we propose the technique of informatrion expression in 3 elements of tactile stimulus that the apparent movement is used with the phantom sensation together. By this technique, two-dimensional vector information can be expressed by 3 elements of tactile stimulus.

The experiment setup is shown in Fig.1. A tactile stimulus element is the circle PZT vibrator of about a diameter $21 \mathrm{~mm}$. Three PZT vibrators are shown with $v_{a}, v_{b}$ and $v_{c}$. $v_{a}, v_{b}$ and $v_{c}$ are attached to each of the fingertips of the index finger, a thumb and the little finger, and it is fixed so that each fingertip may be located in the apex of the equilateral triangle $\Delta v_{a} v_{b} v_{c}$ of 1 side $10 \mathrm{~cm}$. The drive valtage $w_{a}, w_{b}$ and $w_{c}$ of $v_{a}, v_{b}$ and $v_{c}$ is shown with Eq.(1), Eq.(2) and Eq.(3) by the rectangle wave respectively.

$$
\begin{aligned}
& w_{a}(t)=A_{a} \cdot u\left(\frac{t}{T_{a}}\right) \cdot u\left(\frac{t}{T_{o}}-\tau_{a}\right) \\
& w_{b}(t)=A_{b} \cdot u\left(\frac{t}{T_{b}}\right) \cdot u\left(\frac{t}{T_{o}}-\tau_{b}\right) \cdot \\
& w_{c}(t)=A_{c} \cdot u\left(\frac{t}{T_{c}}\right) \cdot u\left(\frac{t}{T_{o}}-\tau_{c}\right) .
\end{aligned}
$$

But, $t$ is time. $A_{a}, A_{b}$ and $A_{c}$ are amplitude. $T_{o}$ is a period. $T_{a}, T_{b}$ and $T_{c}$ are periods under $T_{o} / 2 . \tau_{a}, \tau_{b}$ and $\tau_{c}$ are time delay from $u\left(t / T_{o}\right) . u(t)$ is made $u(t)=u(t+m)$, ( $m=0, \pm 1, \pm 2, \cdots)$ by the periodic function of periodic 1 , and is made Eq.(4) in time section $0 \leq t \leq 1$.

$$
u(t)= \begin{cases}1, & \left(0 \leq t<\frac{1}{2}\right) \\ 0, & \text { otherwise }\end{cases}
$$

The A.M. and the P.S. appear between PZT vibrators by adjusting the parameter amplitude, periods and deley time of Eq.(1), Eq.(2) and Eq.(3). It thinks that parameters in Eq.(1), Eq.(2) and Eq.(3) are set up as follows. $T_{o}=1000 \mathrm{~ms}$, $T_{a}=T_{b}=T_{c}=4 \mathrm{~ms}, \tau_{b}=\tau_{c}=0<\tau_{a}, A_{b}+A_{c}=k A_{a}$ and $A_{b}: A_{c}=\beta: 1$. The P.S. appears in the position of $1: \beta$ between $v_{b}$ and $v_{c}$, because a difference in $v_{b}$ and $v_{c}$ is only amplitude. This is shown with $p_{b c}(\beta)$. But, $\beta$ and $k$ are

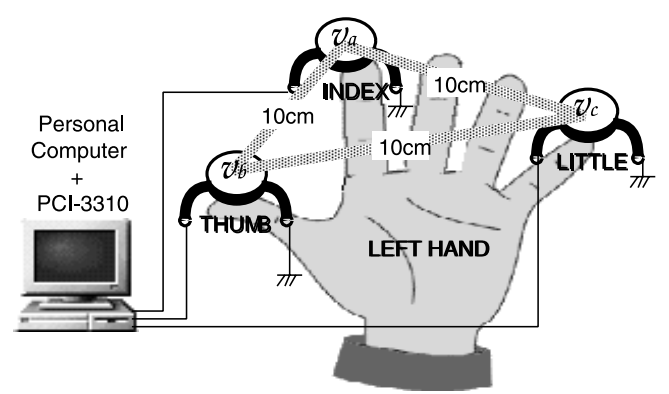

Fig. 1. Experimental setup

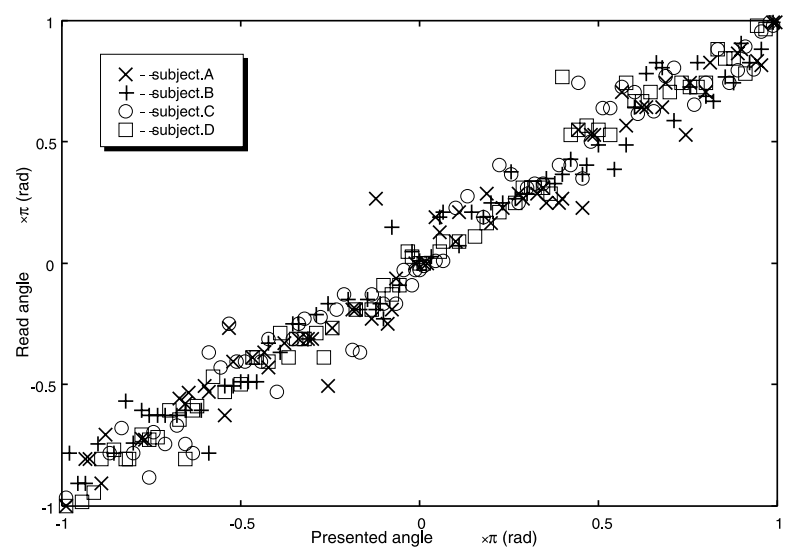

Fig. 2. Relations between presented angle and read angle

optional constants. At the same time, because there is a difference in time delay between $p_{b c}(\beta)$ and $v_{a}$, the A.M. to $v_{a}$ from $p_{b c}(\beta)$ appears between $p_{b c}(\beta)$ and $v_{a}$. Therefore, when this A.M. is used, the expression of vector $\overrightarrow{p_{b c}(\beta) v_{a}}$ to the open interval $(\pi / 3,2 \pi / 3) \mathrm{rad}$ in starting point $p_{b c}(\beta)$ and the vector $\overrightarrow{v_{a} p_{b c}(\beta)}$ to the interval $(-2 \pi / 3,-\pi / 3) \mathrm{rad}$ in starting point $v_{a}$ becomes possible. By the same method, the expression of vector $\overrightarrow{v_{c} p_{a b}(\alpha)}$ to the open interval $(2 \pi / 3, \pi) \mathrm{rad}$ in starting point $v_{c}, \overrightarrow{p_{a b}(\alpha) v_{c}}$ to $(-\pi / 3,0) \mathrm{rad}$ in starting point $p_{a b}(\alpha), \overrightarrow{v_{b} p_{c a}(\gamma)}$ to $(0, \pi / 3) \mathrm{rad}$ in starting point $v_{b}$ and $\overrightarrow{p_{c a}(\gamma) v_{b}}$ to $(-\pi,-2 \pi / 3) \mathrm{rad}$ in starting point $p_{b c}$ becomes possible. When $v_{a}, v_{b}, v_{c}, p_{a b}(\alpha), p_{b c}(\beta)$ and $p_{c a}(\gamma)$ are used, the vector expression from $-\pi$ rad to $\pi \mathrm{rad}$ becomes possible with only 3 vibrators. $\alpha$ and $\gamma$ are optional constants.

The experiment of presenting angle information was done to verify the validity of the proposal technique. The result of the experiment is shown in Fig.2. This experiment was done with 4 subjects. As a result of the experiment, it was found out that a vector expression which made $\pi / 10 \mathrm{rad}$ an angle unit was possible. 


\title{
Phantom sensation と仮現運動を併用した触覚ディスプレイ
}

\author{
非会員 上田 真太郎* 正 員 内田 雅文* \\ 正員 野澤 昭雄 ${ }^{* *}$ 正 員 井出 英人***
}

\author{
A Tactile Display Used Phantom Sensation with Apparent Movement Together
}

Shintaro Ueda*, Non-member, Masafumi Uchida*, Member, Akio Nozawa**, Member, Hideto Ide***, Member

When two and more stimuli are arranged in the space, an illusion such as the phantom sensation and the apparent movement appear in the sense of touch. The foundation research to build a system of presenting two-dimensional information by using the phantom sensation and the apparent movement is done by this research. When the apparent movement is used, information in the direction can be expressed between 2 elements of tactile stimulus in two-dimensional vector information. In this report, we propose the technique of informatrion expression in 3 elements of tactile stimulus that the apparent movement is used with the phantom sensation together. By this technique, two-dimensional vector information can be expressed by 3 elements of tactile stimulus.

キーワード : 触覚ディスプレイ, ファントムセンセーション, 仮現運動, 情報提示

Keywords: tactile display, phantom sensation, apparent movement, information presentation

\section{1. まえがき}

触覚は痛覚, 温覚と共に身体のいたるところに散在する 感覚系, 皮膚感覚であり, ヒトが生活する上で欠かすこと の出来ない感覚である。身体のいたるところに散在すると いう特徴から, 感覚の一部に何らかの障害を生じても, 触 覚が完全に消失してしまうことは稀で, 残余感覚として感 覚代行に有効な感覚器でもある。視覚, 聴覚の感覚代行器 として開発されてきた触覚ディスプレイは, 従来, その多 くが，多数の触刺激素子をアレイ状に配置する構造を前提 としており, その高密度実装化が主要な研究テーマとなっ てきた (1) (3)。しかしながら，もし伝えたい情報が少数の 触刺激素子で十分に伝達できるのであれば, 触刺激素子を

\footnotetext{
*電気通信大学電子工学科

争 182-8585 調布市調布ヶ丘 1-5-1

Department of Electronic Engineering, The University of Electro-Communications

1-5-1, Chofu-ga-oka, Chofu 182-8585

** 明星大学電気電子システム工学科

干 191-8506 日野市程久保 2-1-1

Department of Electronics and Electrical System Engineering, Meisei University

2-1-1, Hodokubo, Hino 191-8506

*** 青山学院大学電気電子工学科

T 229-8558 相模原市淵野辺 5-10-1

Department of Electronics and Electrical Engineering, Aoyama Gakuin University

5-10-1, Fuchinobe, Sagamihara 229-8558
}

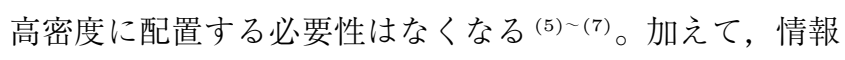
提示装置としての携帯性・利便性 - 保守性 - 低コスト性に おいて性能向上が期待でき, 触覚ディスプレイが新しい情 報提示のツールとして発展する可能性もある。

触覚には, Phantom Sensation(以後, P.S. と記す) と仮 現運動という錯覚が知られている。前者は, 身体部位 2 地 点にそれぞれ触刺激を継時的に提示するとき, 2 つの触刺 激が類似し, かつ同時に提示されると, 2 地点の中間位置 に刺激像 (以後, P.S. 像と記す) が感じられる現象である。 また, P.S. 像は, 2 つ触刺激の刺激強度に差があると, 刺 激強度の大きい触刺激の方向へずれて生じる特性がある。 この特性は, 触刺激素子が置かれていない, 2 つの触刺激 素子間の任意の部位にP.S. 像が生起できることを示してい る。一方, 後者は, 身体部位 2 地点にそれぞれ触刺激を継 時的に提示するとき, 一方の刺激提示ともう一方の刺激提 示との間に適切な時間差があると, 1 つの刺激像が 2 地点 間を連続的に移動しているかのごとく感じられる現象であ る。触覚における P.S. や仮現運動に関する先行研究では, 仮現運動の周波数特性や P.S. 像の配位特性など, 現象の基 礎的な特性が調べられている(8) (13)。特に 3 つの触刺激素 子による 3 点 P.S. に関しては, 機械振動刺激による報告の ほか, 電気パルス刺激を用いた P.S. 像の配位特性, 位置弁 別特性が詳細に報告され, 伝達情報量の観点での検討も行 われている ${ }^{(14)(15)}$ 。情報提示への応用としては, 把持時の 擬似力覚の提示に P.S. を利用する報告がある ${ }^{(16)}$ 。 
本研究では, P.S. と仮現運動を併用し，伝達したい 2 次 元情報をコーディングせず，トポロジカルな性質を保った まま提示する 2 次元触覚ディスプレイの開発を行ってい る ${ }^{(17)(18)}$ 。この 2 次元触覚デイスプレイを 3 つの触刺激素 子で構成し，ベクトル情報を提示するとき，2 触刺激素子 間の仮現運動を用いるのであれば，方向に関しては 6 方向 まで表現できる。本稿では，一般的な 2 触刺激素子間の仮 現運動に加えて, 新たに触刺激素子と P.S. 像を組み合わせ た刺激を構成してベクトル情報を表現する，3 触刺激素子 による情報の提示手法を提案する。また，提案手法による 情報提示に関する実験結果として, $-\pi \sim \pi \mathrm{rad}$ の角度情報 は最大 $\pi / 10 \mathrm{rad}$ を 1 単位として伝達できることを示す。

方向に関する情報を触覚を介して伝える試みとしては, 複 数個の振動子を並ベたベルト型ウェアラブル・インタフェー スを用いて 2 次元空間内の方位を想起させる研究や，方位 センサや GPS を付加してナビゲーションシステムを構築す る研究などがある ${ }^{(19) \sim(21) 。 ま た ， ~} 3$ 触刺激素子による P.S. を用いた情報提示については前述の通りであるが，本稿で 提案する情報提示手法は, P.S. と仮現運動を併用して情報 を伝える点に特徴がある。

\section{P.S. と仮現運動による情報提示}

本研究では，触覚ディスプレイに用いる触刺激に変調振 動を採用している。本稿で想定する 3 つの触刺激素子から なる触覚ディスプレイは，触刺激素子を正三角形 $\Delta v_{a} v_{b} v_{c}$ の各頂点に配置し， $v_{a}, v_{b}, v_{c}$ が接触する身体各部位，例え ば図 1 のように手のひらの 3 部位へ，それぞれ独立に変調 振動刺激を提示できる装置である。

時刻 $t$ において， $v_{a}, v_{b}, v_{c}$ にある各触刺激素子より提示 される刺激強度 $w_{a}(t), w_{b}(t), w_{c}(t)$ はそれぞれ

$$
\begin{aligned}
& w_{a}(t)=A_{a} \cdot u\left(\frac{t}{T_{a}}\right) \cdot u\left(\frac{t}{T_{o}}-\tau_{a}\right) . \\
& w_{b}(t)=A_{b} \cdot u\left(\frac{t}{T_{b}}\right) \cdot u\left(\frac{t}{T_{o}}-\tau_{b}\right) \cdots \\
& w_{c}(t)=A_{c} \cdot u\left(\frac{t}{T_{c}}\right) \cdot u\left(\frac{t}{T_{o}}-\tau_{c}\right) .
\end{aligned}
$$

とする。ただし， $A_{a}, A_{b}, A_{c}$ は振幅， $T_{o}$ は周期, $T_{a}, T_{b}, T_{c}$ は $\frac{T_{o}}{2}$ 未満の周期, $\tau_{a}, \tau_{b}, \tau_{c}$ は $u\left(t / T_{o}\right)$ からの時間遅れで ある。 $u(t)$ は周期 1 の周期関数

$$
u(t)=u(t+m), \quad(m=0, \pm 1, \pm 2, \cdots)
$$

とし， $0 \leq t \leq 1$ において (5) 式とする矩形波である。

$$
u(t)= \begin{cases}1, & \left(0 \leq t<\frac{1}{2}\right) \\ 0, & \text { otherwise }\end{cases}
$$

各触刺激素子から提示される刺激の一例として，(1) 式が 表す波形の模式図を図 2 に示す。

(2),(3) 式に扔いて, $T_{b}=T_{c}$ かつ $\tau_{b}=\tau_{c}=0$ とし,

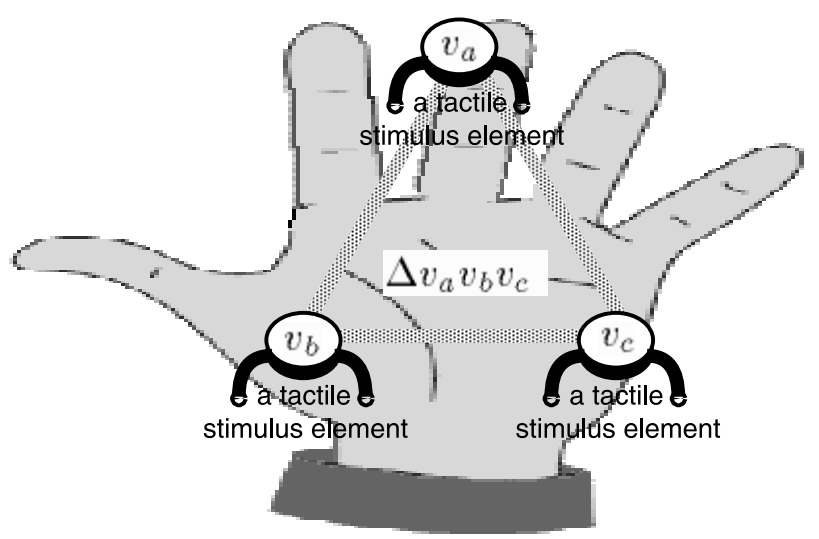

図 13 触刺激素子の配置

Fig. 1. The arrangement of 3 elements of tactile stimulus.

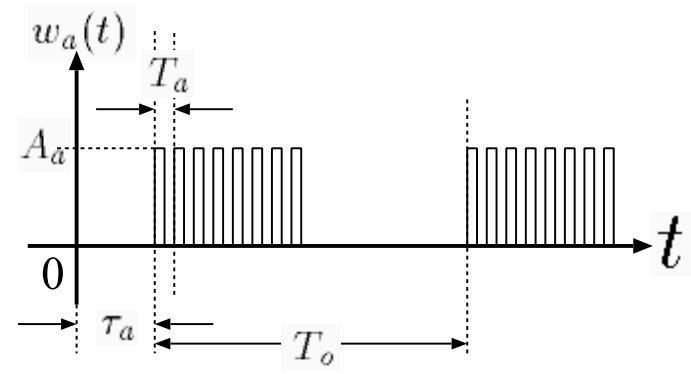

図 2 刺激強度波形の一例

Fig. 2. An example of stimulus waveform.

$A_{b}, A_{c}$ の関倸を

$A_{b}: A_{c}=\beta: 1$

とすると, $v_{b}$ と $v_{c}$ から提示される刺激は振幅のみ異なる 刺激となる。ただし， $\beta$ は $\beta>0$ の任意の定数である。谷 江らは，P.S. 像の配位特性に関して，2 刺激部位間の中央 周辺では線形，刺激部位周辺ではマスキング現象により非 線形になることを報告している ${ }^{(22)}$ 。また，実際の身体は， 部位ごとに刺激に対する感度が異なるものであるが，本稿 ではシステム構成の単純化を考慮し， 3 刺激部位の感度特 性は同等とし，2 刺激部位間の全域に扔いて P.S. 像の配位 特性は線形性を仮定する。すなわち, P.S. 像は線分 $v_{b} v_{c}$ を $1: \beta$ に内分する位置 $p_{b c}(\beta)$ に生起するものとする。仮に, $p_{b c}(\beta)$ と実際の P.S. 像の配位位置との間にズレが生じて いるのであれば，このズレは触覚ディスプレイとしてのシ ステム性能，例えば，情報の伝達精度に反映されるはずで ある。

ここで $A_{a}, A_{b}, A_{c}$ の関係を

$$
A_{b}+A_{c}=k A_{a}
$$

とし, 任意の定数 $k,(k>0)$ を $v_{a}$ と $p_{b c}(\beta)$ の刺激の触感 覚が同程度になるよう調整する。その上で $\tau_{a}$ を $\tau_{a}>0$ で 調整すると, $v_{a}$ の刺激は $p_{b c}(\beta)$ の刺激に対して $\tau_{a}$ だけ時 


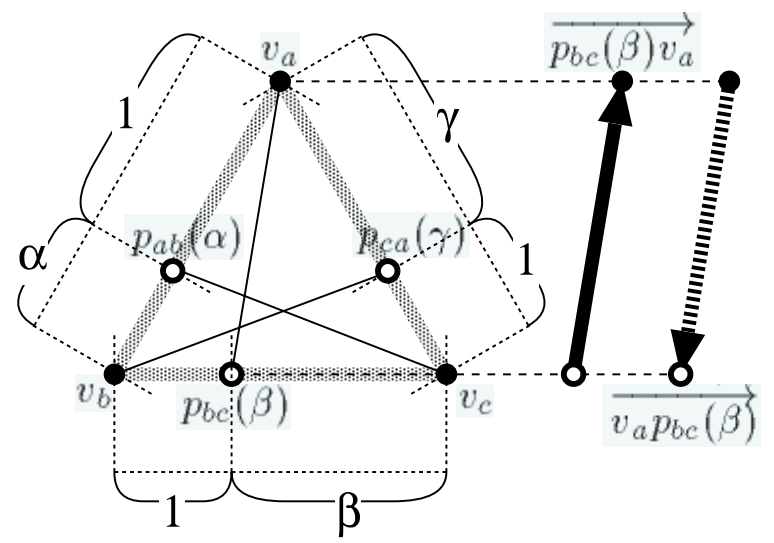

図 33 触刺激素子によるベクトル表現

Fig. 3. The expression of vector by using 3 elements of tactile stimulus.

間遅れが生じているので, $p_{b c}(\beta)$ と $v_{a}$ の間で図 3 実線矢 印のような $p_{b c}(\beta)$ から $v_{a}$ へ向かう大きさ $\left|p_{b c}(\beta) v_{a}\right|$ のべ クトル $\overrightarrow{p_{b c}(\beta) v_{a}}$ が仮定できる。ここで $\tau_{a}, \tau_{b}, \tau_{c}$ の関倸を $\tau_{b}=\tau_{c}>\tau_{a}=0$ に変更し， $\tau_{b}$ を調整すると, $p_{b c}(\beta)$ の刺 激は $v_{a}$ の刺激に対して $\tau_{b}$ だけ時間遅れが生じるので， $v_{a}$ と $p_{b c}(\beta)$ の間で図 3 点線矢印のような $v_{a}$ から $p_{b c}(\beta)$ へ向 かう大きさ $\left|v_{a} p_{b c}(\beta)\right|$ のベクトル $\overrightarrow{v_{a} p_{b c}(\beta)}$ が仮定できる。 $\overrightarrow{p_{b c}(\beta) v_{a}}$ と $\overrightarrow{v_{a} p_{b c}(\beta)}$ は

$$
\overrightarrow{p_{b c}(\beta) v_{a}}=-\overrightarrow{v_{a} p_{b c}(\beta)}
$$

の関倸にあるので, $\beta$ を調整することによりべクトルの方向 は， $\pm \pi / 3 \sim \pm 2 \pi / 3 \mathrm{rad}$ の間で調整できることになる。た だし，(6) 式より $\left.p_{b c}(\beta)\right|_{\beta \rightarrow 0}=v_{c},\left.p_{b c}(\beta)\right|_{\beta \rightarrow \infty}=v_{b}$ なの で, P.S. 像は触刺激素子の刺激で代用し,

$$
\begin{aligned}
& \left.\overrightarrow{v_{a} p_{b c}(\beta)}\right|_{\beta \rightarrow 0}=-\overrightarrow{v_{c} v_{a}} \ldots \ldots \ldots \ldots \ldots \ldots \ldots \ldots \ldots \ldots \ldots \\
& \left.\overrightarrow{v_{a} p_{b c}(\beta)}\right|_{\beta \rightarrow \infty}=\overrightarrow{v_{a} v_{b}} \ldots \ldots \ldots \ldots \ldots \ldots \ldots
\end{aligned}
$$

となる。すなわち $\pm \pi / 3, \pm 2 \pi / 3 \mathrm{rad}$ の 4 方向については, $\pm \overrightarrow{v_{a} v_{b}}, \pm \overrightarrow{v_{c} v_{a}}$ で置換し， 2 触刺激素子間の仮現運動によっ て表現する。

以下，同様にして，線分 $v_{a} v_{b}$ および線分 $v_{c} v_{a}$ をそれぞれ $1: \alpha, 1: \gamma$ に内分する $p_{a b}(\alpha), p_{c a}(\gamma)$ にP.S. 像を仮定する と, 4 種類のベクトル $\pm \overrightarrow{v_{c} p_{a b}(\alpha)}, \pm \overrightarrow{v_{b} p_{c a}(\gamma)}$ が表現でき, べ クトルの方向はそれぞれ，0〜 $\pm \pi / 3 \mathrm{rad}, \pm 2 \pi / 3 \sim \pm \pi \mathrm{rad}$ の間で調整できることになる。ただし， $\alpha, \gamma$ は $\alpha>0, \gamma>0$ の任意の定数である。結果として $-\pi \sim \pi \operatorname{rad}$ の角度情報 は， $\Delta v_{a} v_{b} v_{c}$ の頂点に配置した 3 触刺激素子上で仮定する 2 種類のベクトル，すなわち触刺激素子と P.S. 像からなる ベクトルと 2 触刺激素子間の仮現運動によるべクトルによっ て表現され，3 触刺激素子を通して情報提示されることに なる。

\section{3. 実験方法}

提案した 3 触刺激素子による情報提示の有効性を心理物

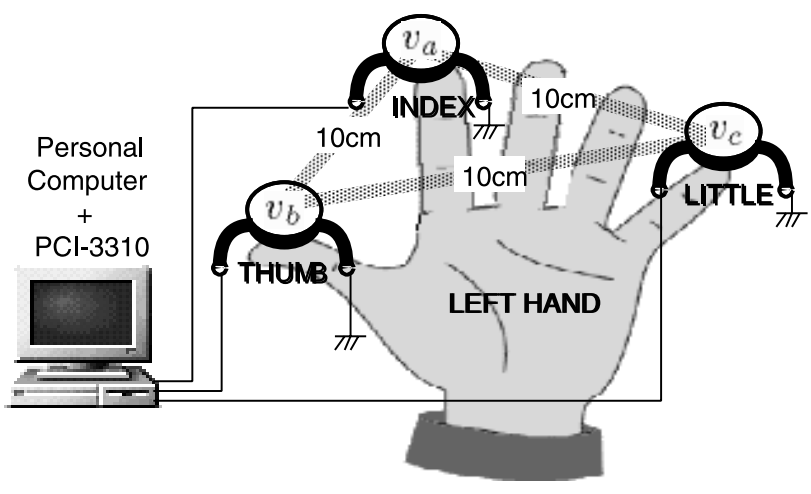

図 4 実験装置

Fig. 4. Experimental setup.

理実験により検証する。

〈3・1〉 実験システム 3 触刺激素子で構成される実験 装置は図 4 の通りである。触刺激素子には直径 $2.1 \mathrm{~cm}$ ，円 盤形の PZT 振動子 (村田製作所製 77B-21-19R7DM-4A0) を用いる。PZT 振動子は, 被験者の左手親指, 示指, 小 指の先端部腹側に市販の伸縮性包带にて装着する。 $v_{a}$ は示 指, $v_{b}$ は親指, $v_{c}$ は小指とし, それぞれが一辺 $10 \mathrm{~cm} の$ $\Delta v_{a} v_{b} v_{c}$ の頂点に位置するよう手を若干, 窄ませて固定, 保持する。PZT 振動子から提示される刺激強度と PZT 振 動子への印加電圧との関係を線形と仮定し, $w_{a}(t) \sim w_{c}(t)$ をPZT 振動子への印加電圧とする。 $w_{a}(t) \sim w_{c}(t)$ の諸パ ラメータは, パーソナルコンピュータに搭載した $\mathrm{D} / \mathrm{A}$ 変 換ボード (Interface 製 PCI-3310)によって制御する。PZT 振動子の振動音が実験へ与える影響を考慮し, 実験中, 被 験者には市販の耳栓と遮音ヘッドフォン (PELTOR 社製 $\mathrm{H} 10 \mathrm{~A})$ を装着させる。

予備実験において $A_{a}=A_{b}=A_{c}=10 \mathrm{~V}, T_{a}=T_{b}=$ $T_{c}=4 \mathrm{~ms}, T_{o}=1000 \mathrm{~ms}$ のとき, 2 触刺激素子間の仮現運 動およびP.S. は生起することを確認している。ただし，こ のときの仮現運動は 2 触刺激素子間の時間遅れ幅が $250 \mathrm{~ms}$ である。

$\langle\mathbf{3} \cdot \mathbf{2}\rangle$ 角度情報伝達実験 提案する 3 触刺激素子に よる情報提示方法を用いて， $-\pi \sim \pi \operatorname{rad}$ の角度情報を提示 し, 情報伝達の可不可の確認, および伝達精度を評価する ための実験である。

実験者が被験者に知覚されることを期待する情報は，6 種 類のベクトル $\pm \overrightarrow{v_{c} p_{a b}(\alpha)}, \pm \overrightarrow{v_{a} p_{b c}(\beta)}, \pm \overrightarrow{v_{b} p_{c a}(\gamma)}$ である。 ここで $\beta$ を(11) 式とすると, $\pm 7 \pi / 20 \sim \pm 13 \pi / 20 \mathrm{rad}$ の 角度情報は, 38 種類のベクトル $\pm \overrightarrow{v_{a} p_{b c}(\beta)}$ によって $\pi / 60$ $\mathrm{rad}$ 刻みで提示されることになる。

$$
\beta=\frac{19-n}{1+n}, \quad(n=0,1,2, \cdots, 17,18) \cdots \cdots
$$

また, $\pm \overrightarrow{v_{a} v_{b}}, \pm \overrightarrow{v_{c} v_{a}}$ は 2 触刺激素子間の仮現運動として, $\pm \pi / 3, \pm 2 \pi / 3 \mathrm{rad}$ を表現するので, $\pm \pi / 3 \sim \pm 2 \pi / 3 \mathrm{rad}$ の 角度情報は, $\pm \overrightarrow{v_{a} p_{b c}(\beta)}, \pm \overrightarrow{v_{a} v_{b}}, \pm \overrightarrow{v_{c} v_{a}}$ 合わせて 42 種類 のベクトルによって $\pi / 60 \mathrm{rad}$ 刻みで提示されることにな 


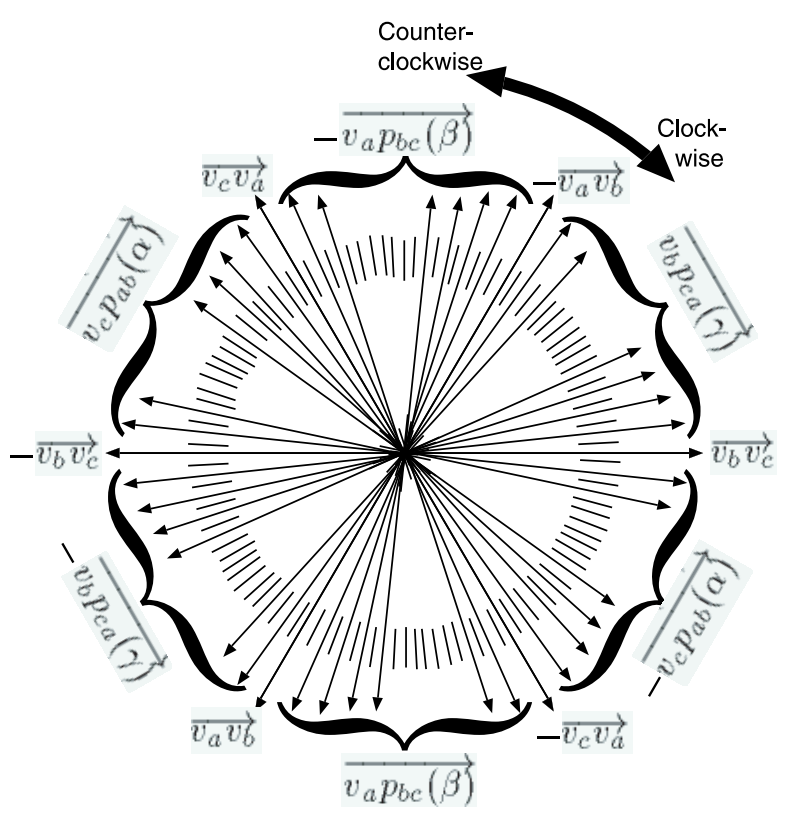

図 5 ベクトルと角度の関係

Fig. 5. Relations between vector and angle.

る。 $\alpha, \gamma$ についても (11) 式と同様に定めると, $-\pi \sim \pi \mathrm{rad}$ の角度情報は, $\pm \overrightarrow{v_{c} p_{a b}(\alpha)}, \pm \overrightarrow{v_{a} p_{b c}(\beta)}, \pm \overrightarrow{v_{b} p_{c a}(\gamma)}, \pm \overrightarrow{v_{a} v_{b}}$, $\pm \overrightarrow{v_{b} v_{c}}, \pm \overrightarrow{v_{c} v_{a}}$ 合わせて 120 種類のベクトルによって $\pi / 60$ $\operatorname{rad}$ 刻みで提示されることになる。以上，定められた 120 種 類のベクトルと各ベクトルが指示する角度との関係は, 戝 5 のようになっている。図はべクトルの始点を共通にして 描いた模式図である。

被験者は，パーソナルコンピュータのモニター正面に座 し，モニターと向かい合う形で位置する。モニター画面に 表示される図 6 のような GUI と左手が形作る $\Delta v_{a} v_{b} v_{c}$ の 位置関係を, GUI の水平方向 $(0 \mathrm{rad}, \pm \pi \mathrm{rad})$ が底辺 $v_{b} v_{c}$, および GUI の垂直方向 $( \pm \pi / 2 \mathrm{rad})$ が点 $v_{a}$ から底辺 $v_{b} v_{c}$ へ下ろした垂線になるよう保持しながら, 以下の手順に従っ て実験を行う。

[Step 1] 120 種類のベクトルの中から任意に 1 ベクト ルを選択し，被験者へ 3 触刺激素子を通して提示する。提 示されたベクトルが表す角度を以後, 提示角度と呼称する。

[Step 2] 被験者は，提示される刺激から角度情報を読 み取り (以後, 読取角度と記す), 図 6 の GUI をマウスに よって操作し， $\pi / 180 \mathrm{rad}$ 単位で読取角度を回答する。実 験開始前には図中左の GUI が表示されており，被験者が "Start" ボタンをクリックすると，図中右のような GUI に切り替わって実験開始となる。この図の中では $\pi / 4 \mathrm{rad}$ 付近を指示している線分が，スクロールバー操作に連動し て原点を中心に回転する指示針である。図中右はスクロー ルバー操作中の図であり，図中左の “Start” ボタンクリッ ク直後は，指示針は $0 \mathrm{rad}$ を指している。被験者は，指示 針が読取角度を指示するようにスクロールバーを調整して “OK”ボタンをクリックする。 3 触刺激素子からの刺激は, “OK”ボタンクリックと同時に停止する。

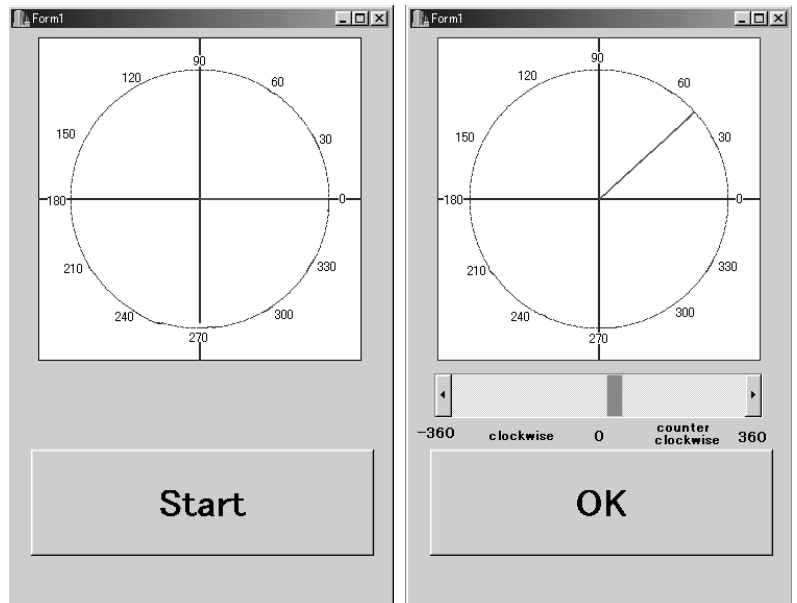

図 6 実験前の GUI と実験中の GUI

Fig. 6. GUI before experiment and GUI during experiment.

[Step 3] パーソナルコンピュータには, 提示角度, 読取 角度，掞よび刺激提示開始から “OK” ボタンをクリックす るまでの所要時間 (以後, 回答時間と記す) が記録される。

以上, Step 1〜3を 6 回繰り返して 1 試行とする。試行と 試行の間には充分な休憩が取られるよう留意しながら，合 計 12 試行を行う。

実験開始前，被験者には実験の主旨，実験手順を文書で 伝えると共に, 実験装置を用いた 1 時間程度のトレーニン グを行う。引続いて, 図 6 の GUIに打けるスクロールバー の操作開始から指示針を所望の角度へ調整して “OK” ボ夕 ンをクリックするまでの所要時間 (以後, 操作時間と記す) を測定する。この測定は試行と試行の間の休㮩時，および 実験終了後も行い，平均的な操作時間を算出する。読取角 度の意思決定からスクロールバーの操作開始までの所要時 間は，読取時間に比べて極めて短く，また，提示角度への 依存性はないものと仮定すると, 回答時間から操作時間を 差し引いた值は, 刺激提示開始から読取角度の意思決定ま での所要時間と見なすことができ，以後，この值を読取時 間と呼称する。

\section{4. 実験結果および考察}

被験者は, 21 24 歳の健常男性 4 名 (A,B,C,D) であ る。本実験は (7) 式中のパラメー夕を $k=1$ として行った ものである。

表 1 は，各被験者における操作時間の平均值・標準偏差 值，および操作角度と操作時間の間の相関係数である。た だし相関係数は，スクロールバーの操作量が操作角度 $0 \mathrm{rad}$ を中心に左右対象であることを考慮し，操作角度の絶対值 と操作時間の間で算出した值になっている。相関係数は 4 被験者共に高々 0.26 程度となり, また, 個々の測定値も概 ね操作時間の平均值を中心に標準偏差值 1.05 1.60s の程 度で分布していた。そこで操作時間は，操作角度に依らず 一定と仮定し，読取時間は，操作時間の平均値を回答時間 
表 1 操作角度と操作時間の間の相関係数と 操作時間の平均值・標準偏差値

Table 1. Correlation coefficient between operation angle and operation time, average of operation time and that standard deviation.

\begin{tabular}{|c|c|c|c|c|}
\hline subject & $\mathbf{A}$ & B & $\mathrm{C}$ & $\mathrm{D}$ \\
\hline correlation coefficient & 0.26 & 0.26 & 0.22 & 0.24 \\
\hline $\begin{array}{c}\text { average of } \\
\text { operation time }\end{array}$ & 3.63 & 3.69 & 3.57 & 2.93 \\
\hline $\begin{array}{cc}\begin{array}{c}\text { standard deviation } \\
\text { of operation time }\end{array} & (\mathrm{s}) \\
\end{array}$ & 1.26 & 1.42 & 1.60 & 1.05 \\
\hline
\end{tabular}

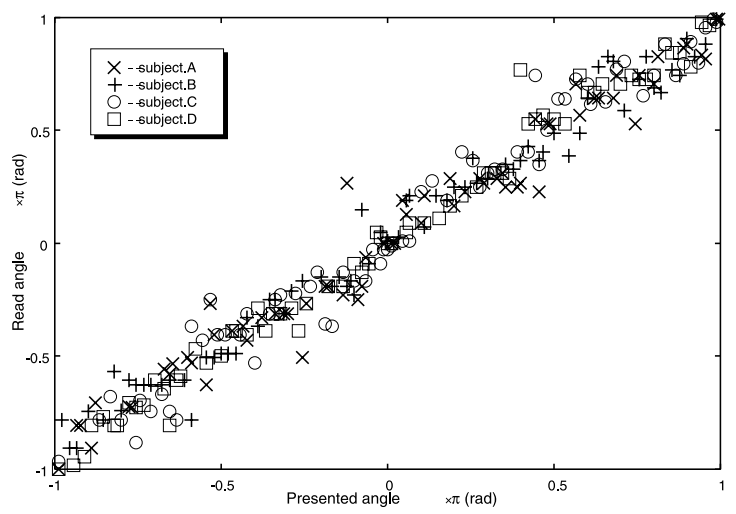

図 7 提示角度と読取角度の関係

Fig. 7. Relations between presented angle and read angle.

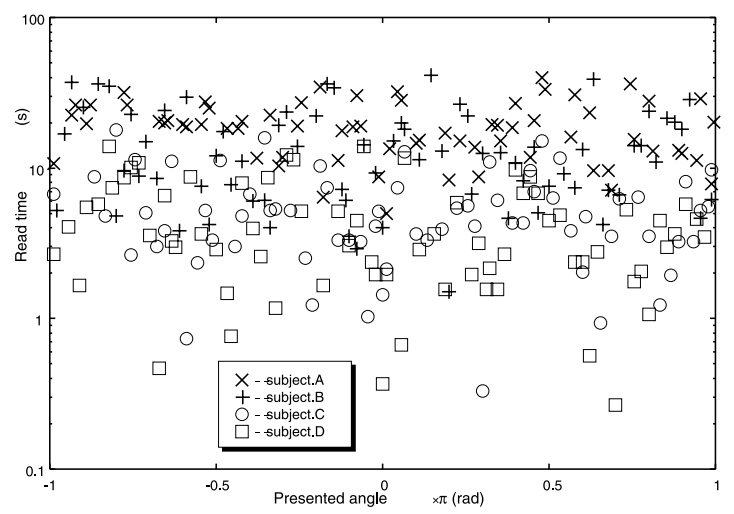

図 8 提示角度と読取時間の関係

Fig. 8. Relations between presented angle and read time.

から差し引くことにより求めることにする。

角度情報伝達実験より得られた提示角度と読取角度の関 係，および提示角度と読取時間の関係を図 7 , 図 8 に示す。 横軸は提示角度， $\times,+, \bigcirc, \square$ 印のプロット点はそれぞれ， 被験者 A,B,C,D からの測定值である。図 7 の縦軸は読取 角度，図 8 の縦軸は読取時間を $\log$ スケールで表している。 提示角度と読取角度の間の相関係数および提示角度に対す る読取角度の偏差の平均值・標準偏差值, 提示角度と読取時 間の間の相関係数および読取時間の平均值・標準偏差值を 表 2 に示す。提示角度と読取角度には強い相関があり，提 示角度に対する読取角度の偏差の平均值は, 若干，提示角 度よりも負の方向へ偏ってはいるものの，ほぼ提示角度を
表 2 読取角度の標準偏差值と読取時間の平均值

Table 2. A standard deviation of read angle and an average of read time.

\begin{tabular}{|cc|c|c|c|c|}
\hline subject & & $\mathbf{A}(\mathbf{d e})$ & $\mathbf{B}(\mathbf{n a})$ & $\mathbf{C}(\mathbf{n i})$ & $\mathbf{D}(\mathbf{t a})$ \\
\hline \hline $\begin{array}{c}\text { correlation coefficient } \\
\text { of read angle }\end{array}$ & & 0.86 & 0.99 & 0.79 & 0.91 \\
\hline $\begin{array}{c}\text { average of } \\
\text { read angle }\end{array}$ & $\times \pi(\mathrm{rad})$ & -0.01 & -0.02 & -0.02 & -0.02 \\
\hline $\begin{array}{c}\text { standard deviation } \\
\text { of read angle }\end{array}$ & $\times \pi(\mathrm{rad})$ & 0.11 & 0.09 & 0.10 & 0.07 \\
\hline $\begin{array}{c}\text { correlation coefficient } \\
\text { of read time }\end{array}$ & $(\mathrm{s})$ & 19.1 & 14.6 & 5.61 & 4.53 \\
\hline $\begin{array}{c}\text { average of } \\
\text { read time }\end{array}$ & $(\mathrm{s})$ & 7.94 & 10.3 & 3.73 & 3.38 \\
\hline $\begin{array}{c}\text { standard deviation } \\
\text { of read time }\end{array}$ & & & & & \\
\hline
\end{tabular}

中心にその周辺，標準偏差值にして $0.07 \pi \sim 0.11 \pi \operatorname{rad}$ の 程度で提示角度は読み取られる結果となった。提示角度に 対する読取角度の偏差の標準偏差值は， $0.07 \pi \sim 0.11 \pi \mathrm{rad}$ と若干の個人差はあるものの， $\pi / 10 \mathrm{rad}$ を 1 単位とすれ ば，十分に情報伝達が可能であることを示唆している。(11) 式で示した通り，本実験では $\Delta v_{a} v_{b} v_{c}$ の頂点間で 19 個の P.S. 像を仮定したが， $\pi / 10 \mathrm{rad}$ 単位で角度情報を伝える には，19 個のうち少なくとも 3 個の P.S. 像が独立した刺 激像として知覚されなければ実現し得ない。したがって本 実験結果は, 直径 $2.1 \mathrm{~cm}$ の $\mathrm{PZT}$ 振動子の間隔 $10 \mathrm{~cm}$, す なわち $\Delta v_{a} v_{b} v_{c}$ の一辺 $10 \mathrm{~cm}$ の間で 3 個以上, P.S. 像を 生起させ, 情報伝達していたことになる。触刺激素子サイ ズに対して高々 5 倍程度の触刺激素子間隔の間で P.S. 像を 3 個以上, 并別できた要因として, 触刺激素子と P.S. 像か らなるべクトル表現の効果を考えているが，この点に関し ては今後，より詳細に調査していく予定である。

提示角度と読取角度の間に非常に強い相関が見られる一 方で，提示角度と読取時間の間にはほとんど相関が見られ なかった。読取時間の平均值は $4.53 \sim 19.1 \mathrm{~s}$ と, 個人差が 非常に大きく，また，その標準偏差值も大きな值を示した ことから，本実験方法が読取時間の個人差を評価するには 適当ではなかったことを窺わせる結果となった。

図 5 が示すように, 触刺激素子と P.S. 像からなるべクト ル $\pm \overrightarrow{v_{c} p_{a b}(\alpha)}, \pm \overrightarrow{v_{a} p_{b c}(\beta)}, \pm \overrightarrow{v_{b} p_{c a}(\gamma)}$ は, 角度幅 $\pi / 3 \mathrm{rad}$ の 6 つの開区間 $(-\pi,-2 \pi / 3),(-2 \pi / 3,-\pi / 3),(-\pi / 3,0)$, $(0, \pi / 3),(\pi / 3,2 \pi / 3),(2 \pi / 3, \pi)$ を分担して情報を伝えて いる。 $\pm \overrightarrow{v_{c} p_{a b}(\alpha)}, \pm \overrightarrow{v_{a} p_{b c}(\beta)}, \pm \overrightarrow{v_{b} p_{c a}(\gamma)}$ がそれぞれ担う 各区間において, 提示角度に対する読取角度の偏差の平均 值・標準偏差值を求めると, 図 9 のようになる。また, 図 10 は, 各区間における読取時間の平均值・標準偏差值で ある。両図とも横軸は各区間で, 左から順に $-\overrightarrow{v_{b} p_{c a}(\gamma)}$, $\overrightarrow{v_{a} p_{b c}(\beta)},-\overrightarrow{v_{c} p_{a b}(\alpha)}, \overrightarrow{v_{b} p_{c a}(\gamma)},-\overrightarrow{v_{a} p_{b c}(\beta)}, \overrightarrow{v_{c} p_{a b}(\alpha)}$ が情 報を担っている。図 9 の縦軸は提示角度に対する読取角度 の偏差である。 $\times,+, \bigcirc, \square$ 印のプロット点はそれぞれ, 被 験者 $\mathbf{A}, \mathbf{B}, \mathbf{C}, \mathbf{D}$ の提示角度に対する読取角度の偏差の平均 值, 各プロット点に付したエラーバーはその標準偏差值を 表している。図 10 の縦軸は読取時間を $\log$ スケールで表し ている。 $\times,+, \bigcirc, \square$ 印のプロット点はそれぞれ, 被験者 $\mathbf{A}, \mathbf{B}, \mathbf{C}, \mathbf{D}$ の読取時間の平均值, 各プロット点に付したエ 


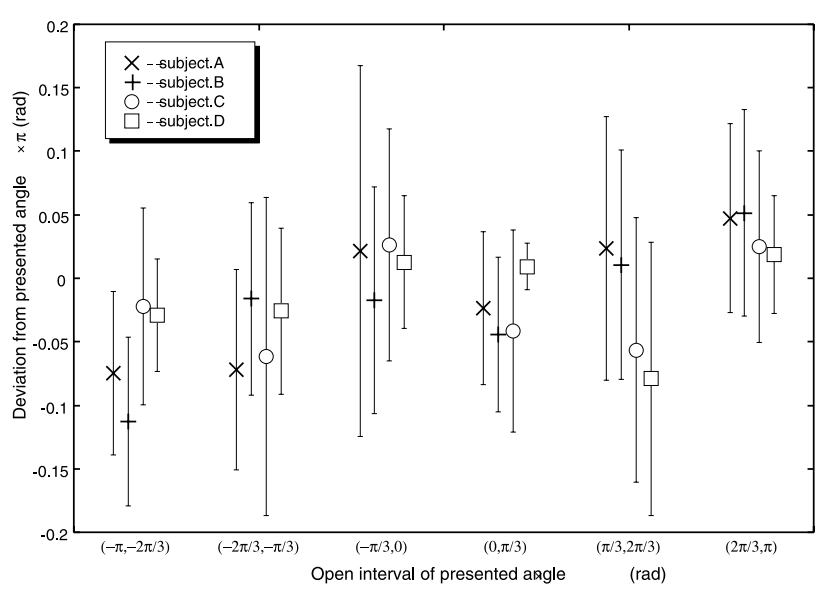

図 9 角度区間と読取偏差角度の関係

Fig. 9. Relations between angle interval and read deviation angle.

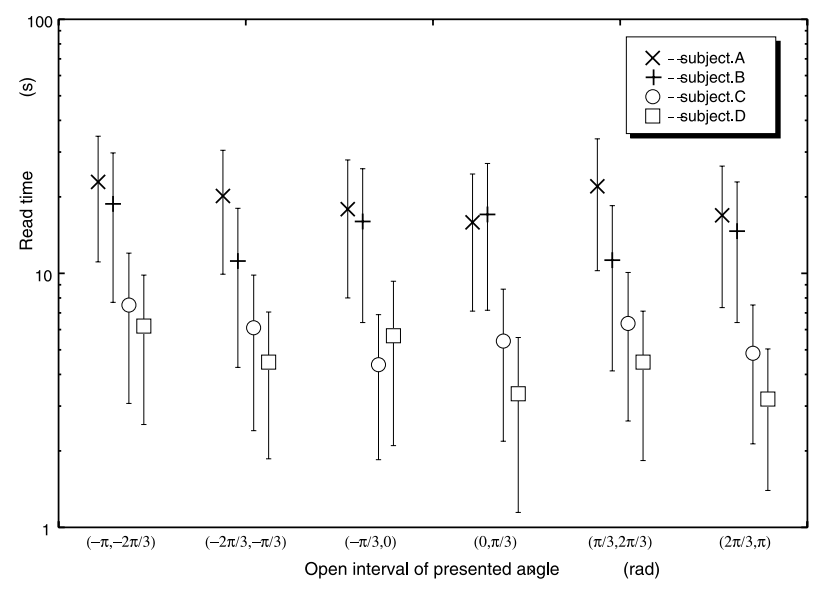

図 10 角度区間と読取時間の関係

Fig. 10. Relations between angle interval and read time.

\section{ラーバーはその標準偏差值である。}

最も安定して精度よく情報伝達できた区間は， $\overrightarrow{v_{b} p_{c a}(\gamma)}$ によって情報伝達された $(0, \pi / 3)$ である。 $\overrightarrow{v_{b} p_{c a}(\gamma)}$ とは土 の関係にある $-\overrightarrow{v_{b} p_{c a}(\gamma)}$ の $(-\pi,-2 \pi / 3)$ には個人差が生 じた。ベクトルの \pm ，すなわち図 3 で示したベクトルの始点 が P.S. 像か触刺激素子かによって情報の伝達性能に差が出 る傾向は, $\pm \overrightarrow{v_{c} p_{a b}(\alpha)}$ の $(-\pi / 3,0),(2 \pi / 3, \pi), \pm \overrightarrow{v_{a} p_{b c}(\beta)}$ の $(-2 \pi / 3,-\pi / 3),(\pi / 3,2 \pi / 3)$ にも見られた。概ね, 触 刺激素子を始点とするべクトルにおいて標準偏差值, 個人 差共に小さく，良好な傾向を示した。1 個の触刺激素子か ら提示される触刺激に比べ，P.S. 像は明らかに鮮明さを欠 いた刺激であり，刺激像としてはぼやけて知覚される。べ クトルの始点，すなわち最初に到来する刺激が鮮明に知覚 されることが，伝達性能を決める要素の 1 つになっている 可能性がある。

表 2 で示した読取角度の負の方向への偏りは, 特に $(-\pi,-2 \pi / 3),(-2 \pi / 3,-\pi / 3),(0, \pi / 3),(\pi / 3,2 \pi / 3)$ の 4 区間，ベクトルにして $\pm \overrightarrow{v_{a} p_{b c}(\beta)}, \pm \overrightarrow{v_{b} p_{c a}(\gamma)}$ で顕著であ
る。一方, $(-\pi / 3,0),(2 \pi / 3, \pi)$ の 2 区間, ベクトルにして $\pm \overrightarrow{v_{c} p_{a b}(\alpha)}$ では, 4 被験者共に正の方向へ偏る結果となっ た。測定值を前者 4 区間と後者 2 区間の 2 群に分け，そ れぞれの母平均に関して有意水準 $5 \%$ で $t$ 検定したところ, 4 被験者共に有意差が認められた。(6) 式および (11) 式が 示す通り，本提案手法は 3 刺激部位の感度特性を同等とし て設計しているが，実際には親指，示指，小指の間で刺激 に対する感度は異なり, 示指が最も良く, 小指が悪い。し たがって, $p_{a b}(\alpha), p_{b c}(\beta), p_{c a}(\gamma)$ はそれぞれ，示指-親指間， 親指-小指間, 小指-示指間の P.S. 像であるが, 実際に生起 する P.S. 像は, 本提案手法が想定している配位位置より も $p_{a b}(\alpha)$ では示指寄り, $p_{b c}(\beta)$ では親指寄り, $p_{c a}(\gamma)$ で は示指寄りに配位しているはずである。この結果として, $\pm \overrightarrow{v_{c} p_{a b}(\alpha)}, \pm \overrightarrow{v_{a} p_{b c}(\beta)}$ は負の方向に, 一方 $\pm \overrightarrow{v_{b} p_{c a}(\gamma)}$ は 正の方向に偏ったものと解釈できる。刺激に対する感度特 性は, 1 被験者の刺激部位間で異なるほか, 当然, 被験者 間でも異なるものであるが，この点については，装置自体 のキャリブレーションによって容易に対応できるものと考 えている。

読取時間の平均值は 4 被験者共に若干ではあるが，右下 がりの傾向を示し, 表 2 中の読取時間の相関係数が 4 被験 者とも負になっていたことと対応している。0〜 $\pi \operatorname{rad} の 3$ 区間の読取時間に比して $-\pi \sim 0 \operatorname{rad} の 3$ 区間の読取時間が 長かった原因の 1 つとして，前述した最初に到来する刺激 の鮮明さとの関連を挙げることができる。前述の通り, 触 刺激素子を始点とするべクトルよりも P.S. 像を始点とす るべクトルは, 情報の伝達性能が劣位にあるとすれば，こ の優劣が情報を読み取る際の難易度に反映され, 読取時間 に影響した可能性がある。- $\pi \sim 0 \mathrm{rad} の 3$ 区間，すなわ $ち-\overrightarrow{v_{b} p_{c a}(\gamma)}, \overrightarrow{v_{a} p_{b c}(\beta)},-\overrightarrow{v_{c} p_{a b}(\alpha)}$ のうち, $-\overrightarrow{v_{b} p_{c a}(\gamma)}$ と $-\overrightarrow{v_{c} p_{a b}(\alpha)}$ の 2 のベクトルは情報の伝達性能が劣位で読み 取り難い，P.S. 像を始点とするべクトルである。一方，0〜 $\pi \operatorname{rad}$ の 3 区間，すなわち $\overrightarrow{v_{b} p_{c a}(\gamma)},-\overrightarrow{v_{a} p_{b c}(\beta)}, \overrightarrow{v_{c} p_{a b}(\alpha)}$ では, P.S. 像を始点とするべクトルは $-\overrightarrow{v_{a} p_{b c}(\beta)}$ だけであ る。したがって本実験方法では， $-\pi \sim 0 \mathrm{rad}$ は， $0 \sim \pi \mathrm{rad}$ に比して P.S. 像を始点とするべクトルが情報伝達を担って いる区間が広く, 結果として提示情報を読み取り難くして 読取時間を伸長させたものと解釈できる。

伝達情報量の観点において今回の実験結果を考察する。 角度情報が $\pi / 10 \mathrm{rad}$ を 1 単位として伝達できるという結果 は， $-\pi \sim \pi$ という数值にコーディングされた情報の伝達と いう観点では，高々5bit 足らずの情報を伝えたに過ぎない。 しかしながら，実験前のトレーニングを含む今回の実験過 程全体を通して, 被験者に正解である提示角度を知らせる ことはなかった。加えて, 提示される触刺激の振動パター ンは 120 種類もあって, 小一時間程度のトレーニングで全 ての振動パターンを記憶することはほとんど困難であった。 当然, 被験者は正解を知らないので, 振動パターンと角度 情報とのコーディングも叶わない。にも関らず， $\pi / 10 \mathrm{rad}$ 程度の精度で情報伝達できたことは，本実験結果が，被験 
者自身が提示された触刺激から感じ取った触刺激の方向性 に関する回答であって，3 触刺激素子が 2 次元べクトルのト ポロジカルな性質を，何らかの形で被験者へ伝えていたこ とを示唆するものである。この観点において伝達情報量は 5bit 以上, 備えているものと考える。一方, 本稿では P.S. 像の配位特性を線形と見なして情報提示のシステムを設計 したが，文献 (22) が指摘する刺激部位周辺での非線形性を 考慮すれば，伝達情報量の更なる向上は十分に可能と考え ている。

\section{5. まとめ}

従来より 2 次元触覚デイスプレイは, 触刺激素子アレイ 上で情報表現するものが一般的である。一方，本研究は，3 つの触刺激素子上で生起する P.S. や仮現運動を利用して 2 次元情報を表現しょうと試みている。本稿では, P.S. と仮 現運動を併用したベクトル情報の提示方法を提案し, その 有効性を角度情報伝達実験を通して検証した。4名の被験 者から得られた結果として, 角度情報は最大 $\pi / 10 \mathrm{rad}$ を 1 単位として伝達できることを確認した。

触刺激素子を少数に抑えることは，そのこと自体，多く のメリットを派生させるが，2次元触覚デイスプレイとして の要件を満たすだけの伝達情報量は確保しなくてはならな い。本稿で示した実験結果は，3 触刺激素子で 5 bit 程度の 伝達情報量を確保したに過ぎないが，P.S. 像の生起する位 置には 3 つ触刺激素子を頂点とする三角形エリア内にお いて自由度があるので，この点において可能性を残してい る。また，本稿では振幅と時間遅れを情報提示のパラメー タとして採用したが，刺激強度波形のパラメータには周期 も利用可能である。これらのパラメータがそれぞれ独立に 機能することを考慮すれば，伝達情報量は更に向上する可 能性がある。

(平成 17 年 6 月 13 日受付, 平成 18 年 10 月 23 日再受付)

\section{文献}

(1) C. Domenici and D. Derossi: "A stress-component-selective tactile sensor array", Sensors Actuators, Vol.13, pp.97-100 (1992)

(2) B.L. Gray and R.S. Fearing: "A surface-micromachined micro-tactile sensor array", IEEE Int. Conf. Rob. and Auto., Vol.1, pp.1-6 (1996)

(3) D. Pawluk, C. Buskirk, J. Killebrew, S. Hsiao, and K. Johnson: "Control and pattern specification for a high density tactile array", IMECE Proc. of the ASME Dyn. Sys. and Control Div., Vol.64, pp.97-102 (1998)

(4) H. Tan and D.J. Reebe: "A Microfablicated Electrostatic Haptics Display for persons with Visual Impairments", IEEE Trans. Rehabiritation Engineering, Vol.6, No.3, pp.241-247 (1998)

(5) M. Uchida, H. Tanaka, H. Ide, and S. Yokoyama: "A Tactile Display by 16 kinds of modulated wave vibration Used Only One PZT Vibrator", T. IEE Japan, Vol.120-C, No.6, pp.825-830 (2000-6) (in Japanese) 内田雅文・田中久弥・井出英人・横山修一 :「単一の PZT 振動子を 用いた 16 種類の変調波振動による触覚ディスプレイ」, 電学論 $\mathrm{C}$, 120, 6, pp.825-830 (2000-6)

(6) T. Shiozaki, M. Uchida, H. Tanaka, A. Nozawa, and H. Ide:
"The Evaluation of Cognition to the Modulated Vibration Stimulus by ERP", T. IEE Japan, Vol.122-C, No.9, pp.15671572 (2002-9) (in Japanese)

塩崎哲也·内田雅文・田中久弥・野澤昭雄 $\cdot$ 井出英人:「事象関連 脳電位による変調振動刺激に対する認知評価」, 電学論 C, 122, 9, pp.1567-1572 (2002-9)

( 7 ) M. Uchida, A. Nozawa, and H. Ide: "Difference Evoluation to Modulated Vibration Stimuli by Using Single Trial Waveform of ERP", IEEJ Trans. EIS, Vol.124, No.1, pp.73-78 (2004-1) (in Japanese)

内田雅文・野澤昭雄・井出英人:「ERP の単一試行波形を用いた変調振 動刺激に対する弁別評価」, 電学論 C, 124, 1, pp.73-78 (2004-1)

(8) J.H. Kirman: "Tactile apparent movement: The effects of interstimulus onset interval and stimulus duration", Perception \& Psychophysics, Vol.15, pp.1-6 (1974)

(9) J.H. Kirman: "Tactile apparent movement: The effects of number of stimulators", J. Experimental Psychology, Vol.103, pp.1175-1180 (1974)

(10) J.H. Kirman: "Tactile apparent movement: The effects of shape and type of motion", Perception \& Psychophysics, Vol.34, No.1, pp.96-102 (1983)

(11) G. von Bekesy: "Neural Funneling along the Skin and between the Inner and Outer Hair Cells of the Cochlea", $J$. Acoust. Soc. Am., Vol.31, No.2, pp.1236-1249 (1959)

(12) D.S. Alles: "Information Transmission by Phantom Sensation", IEEE Trans. Man Machine Systems, MMS-11-1, pp.85-91 (1970)

13) K. Tanie, S. Tachi, K. Komoriya, and M. Abe: "Basic Study on Discriminablity of Mental Location of Electrocutaneous Phantom Sensation", Trans. Soc. ICE, Vol.15, No.4, pp.505512 (1979) (in Japanese)

谷江和雄・舘 暲・小森谷清・阿部 稔:「電気パルス刺激におけ る強度差ファントムセンセーション像の位置弁別特性」, 計測自動 制御学論, 15, 4, pp.505-512 (1979)

(14) K. Tanie, S. Tachi, K. Komoriya, M. Abe, K. Asaba, and Y. Tomita: "Information Transmission Characteristics of TwoDimensional Electrocutaneous Phantom Sensation", Trans. Soc. ICE, Vol.16, No.5, pp.732-739 (1980) (in Japanese) 谷江和雄・舘 暲・ 小森谷清·阿部 稔・浅羽樹一郎・富田良幸: 「電気刺激 3 点ファントムセンセーション像の情報伝達特性」, 計測 自動制御学論, 16, 5, pp.732-739 (1980)

(15) R.W. Mann: "Force and Position Proprioception for Prostheses", The Control of Upper-Extremity Prostheses and Orthoses, pp.201-219, Charles C Thomas Publisher (1974)

(16) A. Shirai, Y. Kume, M. Tsuda, and T. Hatada: "Haptic Phantom Sensation for Interacting with 3D Images", Technical Report of IEICE, IE96-119, pp.77-84 (1997) (in Japanese) 白井暁彦・久米祐一郎・津田元久·畑田豊彦:「皮膚感覚のファント ムセンセーションを用いた 3 次元画像との対話システム」, 信学技 報, IE96-119, pp.77-84 (1997-2)

(17) S. Kezuka, M. Uchida, H. Tanaka, A. Nozawa, and H. Ide: "A Consideration about Figure Presentation of Tactile Display Using the Modulated Vibration", The Papers of Technical Meeting on Instrumentation and Measurement, IEE Japan, IM-03-82 97, pp.71-74 (2003-12) (in Japanese)

毛塚修一・内田雅文・田中久弥・野沢昭雄・井出英人：「変調振動を 用いた触覚ディスプレイの図形情報提示に関する一考察」, 電気学 会計測研資，IM-03-82 97, pp.71-48 (2003-12)

(18) S. Ueda and M. Uchida: "A Basic Characteristic for a Tactile Display by Using Apparent Movement", The Papers of Technical Meeting on Instrumentation and Measurement, IEE Japan, IM-03-82 97, pp.75-78 (2003-12) (in Japanese) 上田真太郎・内田雅文：「仮現運動を利用した触覚ディスプレイの ための基礎特性」, 電気学会計測研資, IM-03-82 97, pp.75-78 (2003-12)

(19) A. Yamamoto, T. Izumi, S. Shirogane, S. Kojima, T. Tanaka, S. Ino, and T. Ifukube: "Two-dimensional Directional Perception Using Vibro-tactile Sense", Human Interface Symposium 2002, pp.21-24 (2002) (in Japanese) 山本哲正 · 泉隆・白銀暁・小島 悟 · 田中敏明 ·井野秀一 . 伊福部達：「振動触覚刺激による二次元方位知覚特性」, ヒューマン インターフェースシンポジウム 2002, pp.21-24 (2002-9)

(20) T. Izumi, A. Yamamoto, S. Shirogane, T. Tanaka, H. Kuroki, S. Ino, and T. Ifukube: "Directional Information Interface Using Vibro-tactile Sense", Proc. of 8th VRSJ Annual Conference, pp.257-260 (2003-9) (in Japanese) 


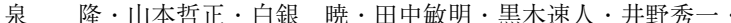
伊福部達:「振動触覚を利用した方位情報提示インターフェースの設 計」, 日本バーチャルリアリテイ学会第 8 回大会論文集, pp.257-260 (2003-9)

(21) K. Tukada and T. Yasumura: "Active Belt: Belt-type Wearable Tactile Display for Directional Navigation", IPSJ Trans., Vol.44, No.11, pp.2649-2658 (2003) (in Japanese) 塚田浩二・安村通晃:「Active Belt:触覚情報を用いたベルト型ナビ ゲーション機構」, 情報処理学論, 44, 11, pp.2649-2658(2003)

(22) K. Tanie and S. Tachi: Report of Mechanical Engineering Laboratory, No.106, pp.52-85 (1980-3) (in Japanese) 谷江和雄·舘 暲: 機械技術研究所報告, No.106, pp.52-85 (19803)

上 田 真太郎 (非会員) 電気通信大学大学院 EC 科博士前期課

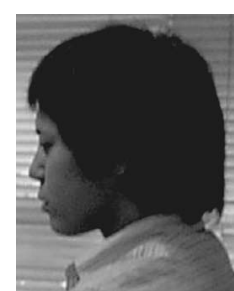

程 (電子工学専攻) 修了。現在, トヨ夕自動車 (株) 勤務。

内田 雅 文

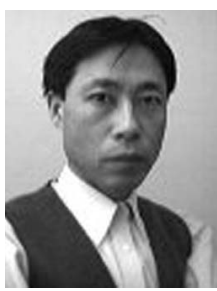

(正員) 1990 年工学院大学大学院工学研究科修 士課程修了 (電気工学専攻)。青山学院大学理工学 部電気電子工学科助手, 和歌山大学教育学部助教 授を経て現在，電気通信大学電気通信学部電子工 学科助教授。主に移動ロボット, 生体計測, 感覚 代行に関する研究に従事。工博。IEEE，日本口 ボット学会会員。
野 澤 昭 雄 （正員） 1997 年青山学院大学大学院理工学研究

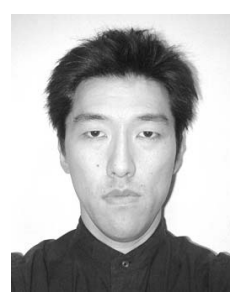
科博士前期課程修了。青山学院大学理工学部電気 電子工学科助手を経て, 現在, 明星大学電気電子 システム工学科講師。主にアントアルゴリズム, 生体計測，感情工学の研究に従事。電子情報通信 学会会員。

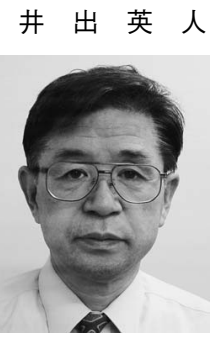

（正員） 1970 年工学院大学大学院工学研究科修 士課程修了 (電気工学専攻)。1985 年 UCLA 応用 科学科客員研究員。1986 年 UCLA 脳研究所客員 教授。感覚の計測，感覚代行の研究に従事。青山 学院大学理工学部講師, 助教授を経て, 現在, 同 教授。工博。日本ロボット学会, 電子情報通信学 会, 計測自動制御学会会員。 